\title{
ANALISIS BIAYA PRODUKSI DALAM PENETAPAN HARGA JUAL DIGITAL PRINTING PADA CV. FORTUNNAADVERTISING KOTA BENGKULU
}

\author{
Suwarni, Kaulan, Sahridi Yanopi \\ Program Studi Manajemen, Fakultas Ekonomi Universitas Dehasen Bengkulu \\ suwarni.h13@gmail.com
}

\begin{abstract}
ABSTRAK
Suwarni, Kaulan, Sahridi Yanopi; Penelitian ini bertujuan untuk mengetahui biaya produksi dengan metode full costing dan harga jual tetap menggunakan metode cost plus pricing pada CV. Periklanan Fortunna kota bengkulu pada tahun 2015 hingga 2017. Metode penelitiannya adalah manifold diskkriptif dan metode pengumpulan data menggunakan observasi dan dokumentasi.

Dari perhitungan biaya produksi dengan menggunakan metode full costing dengan masing-masing laba yang diharapkan 30\% sehingga diperoleh biaya produksi untuk banner pada tahun 2015 sehingga biaya produksi sebesar Rp.17.587, - perencanaan laba untuk Rp.5.276, - dan pengaturan harga jualRp. 22.863.pada tahun 2016 biaya produksi sebesar Rp.17.637, - perencanaan laba sebesar Rp.5.301 dan penetapan harga jual sebesar Rp.22.938, - sedangkan pada tahun 2017 biaya produksi sebesar Rp.17.852, perencanaan laba dari Rp. 5.355, - harga jual Rp. 23.207, -. Untuk produksi papan reklame permeter pada tahun 2015 biaya produksi sebesar Rp.20.040, - perencanaan laba sebesar Rp.6.012, - dan menetapkan harga jual sebesar Rp.26.052, - pada tahun 2016 biaya produksi sebesar Rp.20.008, - merencanakan laba sebesar .Rp.6.002, - dan menetapkan harga jual Rp.26.010, - sedangkan untuk 2017 biaya produksi sebesar Rp.20.168, - perencanaan laba sebesar Rp.6.050, - dan menetapkan harga jual sebesar Rp.26.218, -. Dengan demikian menunjukkan bahwa CV. Periklanan dalm Fortunna menghasilkan barang telah menghitung biaya produksi yang sesuai.
\end{abstract}

\begin{abstract}
Suwarni, Kaulan, Sahridi Yanopi; This study aims to determine the production cost with a full costing method and fixed selling price using cost plus pricing method on the CV. Fortunna advertising bengkulu city in 2015 through 2017. The research method is manifold diskkriptif and methods of data collection using observation and documentation.

From the calculation of cost of production by using the full costing method with each of the expected profit of $30 \%$ so as to obtain the cost of production for the banner in 2015 that the cost of production amounted to Rp.17.587,- profit planning for Rp.5.276,- and setting the selling priceRp. 22.863.- in 2016 the cost of production amounted to Rp.17.637,- profit planning for Rp.5.301 and setting the selling price amounted to Rp.22.938,- whereas in 2017 the cost of production amounted to Rp.17.852,- planning profit of Rp. 5.355,selling price of Rp. 23.207,-. For the production of billboards permeter in 2015 the cost of production amounted to Rp.20.040, - profit planning for Rp.6.012,- and setting the selling price amounted to Rp.26.052,in 2016 the cost of production amounted to Rp.20.008,- planning a profit of .Rp.6.002,- and setting the selling price of Rp.26.010,- whereas for 2017 the cost of production amounted to Rp.20.168,- profit planning for Rp.6.050,- and setting the selling price amounted to Rp.26.218,-. Thus showing that CV. Advertising Fortunna preformance produce goods has calculated the costs of production accordingly.
\end{abstract}

\section{Key Words: Raw Material Costs, Labor Costs Jump and Factory Overhead}

\section{LATAR BELAKANG}

Kelangsungan hidup dan perkembangan perusahaan merupakan tujuan utama yang ingin diwujudkan bagi setiap perusahaan. Sehingga perusahaan perlu membuat strategi dan memerlukan informasi yang memadai guna kelangsungan tumbuh kembangnya perusahaan dimasa yang akan datang. Pada dasarnya perusahaan mempunyai tujuan masing-masing, baik dalam jangka pendek maupun jangka panjang. Adapun tujuan utama yang ingin dicapai oleh perusahaan ialah memperoleh laba (profit margin) semaksimal mungkin, serta meminimalkan biaya produksi dan mempertahankan kelangsungan usahanya. Adapun besar kecilnya laba yang dapat dicapai merupakan ukuran bagi keberhasilan manajemen dalam mengelola perusahaanya. Oleh karena itu manajemen harus mampu untuk merencanakan sekaligus untuk mencapai laba yang telah direncanakan. Perencanaan laba harus dilakukan dengan cermat agar perusahaan berada dalam kondisi yang menguntungkan. 
Untuk mencapai tujuan di atas semua perusahaan baik perusahaan dagang maupun industri tidak terlepas dari masalah penentuan harga pokok produksi. Harga pokok produksi merupakan alat untuk mengetahui harga jual, penetapan laba dan penilaian efisien. Perhitungan harga pokok produksi merupakan salah satu unsur penting dalam menghitung hasil usahanya, untuk itu perusahaan harus mampu mengalokasikan dan mengelolah biaya-biaya produksi yang dipakai secara tepat dan efisien agar tidak terjadi pemborosan.

Didalam penentuan harga pokok produksi terdapat dua metode yang digunakan yaitu metode harga pokok penuh (full costing) dan metode harga pokok variabel (variable costing). Perbedaan pokok antara metode full costing dan variable costing terletak pada perlakuan biaya tetap produksi tidak langsung. Adapun unsur biaya dalam metode full costing terdiri dari biaya bahan baku, biaya tenaga kerja langsung dan biaya overhead pabrik tetap maupun yang variable. Sedangkan unsur biaya variable costing terdiri dari biaya bahan baku, biaya tenaga kerja langsung dan biaya overhead pabrik yang sifatnya variable saja. Menurut metode full costing, biaya overhead pabrik diperhitungkan dalam harga pokok, sedangkan dalam variablecosting biaya diperlakukan sebagai biaya periodik.

Penentuan harga jual suatu barang dan jasa merupakan penentu bagi permintaan pasar, karena penetapan harga dapat mempengaruhi posisi persaingan perusahaan dan juga mempengaruhi permintaan. Apabila perusahaan dalam menetapkan harga jual yang salah maka akan berakibat pada masalah keuangan perusahaan dan akan mempengaruhi kelangsungan usaha perusahaan seperti, terjadi kerugian yang terus menerus atau menimbulnya produksi di gudang karena macetnya dipasaran. Oleh karena itu didalam penentuan harga jual produksi sangat dipengaruhi oleh biaya bahan baku, biaya tenaga kerja langsung dan biaya overhead pabrik.

CV. Fortunna Advertising yang berlokasi di Jl. Merapi Raya No. 35 Rt. 05 Kel. Kebun Tebeng Kec. Ratu Agung Bengkulu, merupakan salah satu usaha yang bergerak di bidang percetakan, dimana produkproduk yang dihasilkan seperti konstruksi billboard, cetak baliho dan spanduk, papan merek usaha, dan lain-lain.

Dari pengamatan yang dilakukan terhadap CV. Fortunna Advertising Kota Bengkulu, perusahaan ini berproduksi berdasarkan pesanan, yaitu dimana produksi yang dihasilkan atas dasar pesanan dan tergantung pada permintaan konsumen. Selain itu perusahaan dalam menetapkan harga jual masih mengikuti harga standar yang berlaku dipasaran, dan dalam menetapkan harga pokok produksi masih menggunakan cara sederhana dimana dalam menentukan harga pokok produksi hanya memperhitungkan biaya-biaya yang berkaitan langsung dengan biaya produksi. Semakin tingginya persaingan di dunia usaha akan menyebabkan turunya keuntungan yang diharapkan. Untuk mempertahankan kelangsungan hidupnya perusahaan harus memperhitungkan harga pokok produksi dengan tepat sehingga dapat menetapkan harga jual yang tepat bagi perusahaan.

\section{LANDASAN TEORI}

\section{Biaya}

Didalam pelaksanaan proses produksi tidak terlepas oleh biaya. Karena biaya merupakan salah satu variabel yang penting sebagai tolak ukur perusahaan dalam mengoprasikan usahanya, dan sebagai penentuan laba yang diharapkan oleh prusahaan. Dan didalam standar akuntansi, biaya digunakan sebagai perencanaan dan pengendalian, perbaikan kualitas dan efisiensi, serta pembuatan keputusan yang bersifat rutin maupun strategis dalam perusahaan.

Biaya mempengaruhi harga karena biaya mempengaruhi penawaran, biaya dapat membantu perusahaan dalam memutuskan tingkat output yang akan memaksimalkan laba operasi. Adapun pengertian biaya menurut para ahli adalah sebagai berikut.

Menurut Dunia dan Wasilah (2009:22) mengatakan bahwa biaya (cost) adalah pengeluaranpengeluaran atau nilai pengorbanan untuk memperoleh barang atau jasa yang berguna untuk masa yang akan datang atau mempunyai manfaat melebihi atau periode akuntansi tahunan. Sedangkan menurut Muqodim (2005:142) mengatakan bahwa biaya adalah aliran keluar atau penggunaan aktiva, atau terjadinya utang (atau kombinasi diantara keduanya) dari penyerahan atau produksi barang, penyerahan jasa atau pelaksanaan kegiatan utama suatu perusahaan.

Biaya merupakan pengorbanan sumber ekonomi, yang diukur dalam satuan uang, yang telah terjadi atau yang kemungkinan akan terjadi untuk tujuan tertentu. Dan biaya merupakan kas atau nilai yang setara kas yang dikorbankan untuk produk yang diharapkan dapat membawa keuntungan masa kini dan masa yang akan datang bagi organisasi.

Menurut Mulyadi (2005:8) biaya adalah pengorbanan sumber ekonomis yang diukur dalam satuan uang, yang telah terjadi, sedang terjadi atau yang kemungkinan akan terjadi untuk tujuan tertentu. Dari defenisi ini, ada empat unsur pokok dalam biaya yaitu:

1.Biaya merupakan pengorbanan sumber ekonomi. 
2.Diukur dalam satuan uang.

3.Yang telah terjadi atau kemungkinan tejadi.

4.Pengorbanan tersebut untuk memperoleh manfaat saat ini dan mendatang.

Menurut Hansen dan Mowen dalam Firtiasari dan Kwary (2009:40) pengertian biaya adalah sebagai berikut:

"Biaya adalah kas atau nilai ekuivalen kas yang dikorbankan untuk mendapatkan barang atau jasa yang diharapkan memberi manfaat saat ini atau dimasa yang akan datang bagi organisasi. Dikatakan ekuivalen kas karena sumber non kas dapat ditukar dengan barang atau jasa yang diinginkan."

Beban adalah arus keluar aktiva atau pengguna lainya atas aktiva atau yang terjadi kewajiban entitas yang disebabkan oleh pengiriman atau pembuatan barang, pemberian jasa, atau aktivitas lainya yang merupakan operasi utama atau operasi sentral perusahaan.

Menurut Ikatan Akuntan Indonesia (2007:18) mendefinisikan beban (expense) adalah sebagai berikut:

"Beban (expense) adalah penurunan manfaat ekonomi selama suatu periode akuntansi dalam bentuk arus keluar dan berkurangnya aktiva atau terjadinya kewajiban yang mengakibatkan penurunan ekuitas yang tidak menyangkut pembagian kepada penanaman modal."

Menurut Mulyadi (2007:24) definisi biaya dibagi atas dua yaitu biaya dalam arti luas dan dalam arti sempit. Dalam arti luas biaya adalah pengorbanan sumber ekonomi yang diukur dalam satuan uang yang telah terjadi dan kemungkinan akan terjadi untuk tujuan tertentu sedangkan dalam arti sempit, biaya diartikan sebagai pengorbanan sumber ekonomi untuk memperoleh aktiva.

Dari beberapa definisi diatas, dapat dijelaskan bahwa istilah biaya (cost) dan beban (expense) memiliki pengertian yang berbeda. Biaya adalah kas atau setara kas yang dikeluarkan perusahaan dengan tujuan untuk mendapatkan manfaat atas biaya tersebut. Manfaat tersebut biasanya pendapatan yang diterima perusahaan akibat mengeluarkan biaya. Sedangkan beban adalah pengorbanan yang dikeluarkan perusahaan unuk mendapat masa manfaat dimasa yang akan datang. Manfaat yang dimaksud adalah manfaat atas penggunaan sumber daya dan bukan termasuk klarifikasi upaya perusahaan dalam mendapatkan pendapatan.

Letak perbedaan biaya dan beban adalah dibagian manfaat yang diperoleh. Manfaat yang diperoleh untuk klarifikasi biaya adalah pendapatan, sedangkan manfaat yang diperoleh untuk klarifikasi beban adalah penggunaan sumber daya.

\section{Biaya Produksi}

Biaya produksi adalah sebagian atau keseluruhan faktor produksi yang dikorbankan dalam proses produksi untuk menghasilkan suatu produk barang. Dalam rencana kegiatan perusahaan, biasanya biaya produksi dihitung berdasarkan jumlah produk yang sudah siap jual. Biaya produksi sering juga disebut sebagai ongkos produksi. Secara umum, biaya produksi di definisikan sebagai keseluruhan biaya yang dikorbankan atau dikeluarkan untuk menghasilkan produk hingga produk itu siap jual sampai dipasaran atau pun langsung ke tangan konsumen. Biaya produksi dapat meliputi unsurunsur sebagai berikut :

a. Bahan baku atau bahan dasar termasuk bahan setengah jadi.

b. Bahan bahan pembantu atau bahan penolong.

c. Upah tenaga kerja semua karyawan.

d. Uang modal, sewa.

e. Penyusutan peralatan produksi.

f. Biaya penunjang seperti biaya angkut, biaya administrasi, pemeliharaan, biaya listrik, biaya keamanan dan asuransi.

g. Biaya pemasaran seperti biaya iklan.

h. Pajak.

Adapun definisi biaya produksi menurut Hansen dan Mowen (2004:50) yaitu biaya yang bekaitan dengan pembuatan barang dan penyediaan jasa. Menurut Usry (2005:24) biaya produksi adalah jumlah dari tiga unsur biaya yaitu biaya produksi langsung, biaya tenaga kerja langsung, dan biaya overhead pabrik. Sedangkan menurut Sukirno (2003:34) biaya produksi dapat didefinisikan sebagai semua pengeluaran yang dilakukan oleh perusahaan untuk memperoleh faktor-faktor produksi dan bahan-bahan mentah yang akan digunakan untuk menciptakan barang-barang yang di produksi perusahaan tersebut. Secara garis besar, cara memproduksi produk dapat dibagi dua macam yaitu produksi atas dasar pesanan dan produksi massa atau proses. Perusahaan yang berproduksi berdasarkan pesanan melaksanakan pengelolahan produknya atas dasar pesanan yang diterima dari 
pihak luar, contoh perusahaan yang berproduksi berdasarkan pesanan adalah perusahaan percetakan, perusahaan mebel, perusahaan dok kapal. Perusahaan yang berproduksi berdasarkan produk masa melaksanakan pengolahan produksinya untuk memenuhi persedian di gudang. Umumnya produknya berupa produk standar, contohnya adalah perusahaan semen pupuk, makan ternak, makanan ringan dan tekstil.

Perusahaan yang berproduksi berdasarkan pesanan, mengumpulkan biaya produksinya dengan menggunakan metode cost pesanan. Dalam metode ini biaya-biaya produksi dikumpulkan untuk pesanan tertentu dan cost produksi persatuan produk yang dihasilkan untuk memenuhi pesanan tersebut dihitung dengan cara membagi total biaya produksi untuk pesanan tersebut dengan jumlah satuan produk dalam pesanan yang bersangkutan. Metode penentuan cost produksi adalah memperhitungkan unsur-unsur biaya ke dalam cost produksi.

\section{Harga Pokok Produksi}

Bagi sebuah perusahaan harga pokok merupakan hal yang sangat penting, karena itu harga pokok tersebut hendaknya disusun secara tepat dan rasional yaitu biaya-biaya yang dibebankan sebagai harga pokok dapat menunjukan hal yang wajar, dengan kata lain bahwa unsur-unsur harga pokok sendiri dapat dialokasikan sesuai dengan fungsinya masing-masing. Harga pokok dalam akuntansi biaya disebut pula sebagai biaya pokok produksi atas pembuatan suatu produk. Harga pokok produksi tidak dapat dipisahkan dari persoalan yang menyangkut biaya, karena biaya merupakan unsur yang menentukan harga pokok suatu produk. Biaya merupakan bagian dari pada harga pokok produksi yang dikorbankan dalam usaha untuk memperoleh penghasilan. Sedangkan harga pokok dapat pula disebut harga beli aktiva yang ditunda pembebananya di masa yang akan datang. Sehingga dapat dikatakan bahwa biaya produksi adalah biaya yang terjadi dalam hubunganya dengan proses pengolahan bahan baku menjadi produk jadi. Biaya produksi dapat dibagi menjadi tiga elemen yaitu biaya bahan baku, biaya tenaga kerja langsung dan biaya overhead pabrik.

Menurut Sukirno (2008:207) menyebutkan harga pokok produksi adalah semua pengeluaran yang dilakukan perusahaan untuk memperoleh faktor-faktor produksi dan bahan mentah yang akan digunakan untuk menciptakan barang-barang yang akan diproduksikan untuk perusahaan tersebut. Menurut Witjaksono (2006:25) mengemukakan bahwa harga pokok produksi tata cara atau metode penyajian informasi biaya produk dan jasa berdasarkan informasi dari sistem akuntansi biaya dan sistem biaya. Sehingga perhitungan harga pokok dilakukan dengan menjumlahkan seluruh unsur biaya produksi, sedangkan harga pokok produksi perunit ditentukan dengan membagi seluruh total biaya produksi dengan volume produksi yang dihasilkan atau yang diharapkan akan dihasilkan.

Berdasarkan pengertian diatas dapat dikatakan bahwa harga pokok produksi adalah semua biaya, baik langsung maupun tidak langsung yang dikeluarkan untuk memproduksi suatu barang selama periode tertentu. Tujuan harga pokok produksi dalam buku akuntansi biaya adalah:

a. Biaya produksi merupakan salah satu data yang dipertimbangkan selain data non produksi dalam penentuan harga jual produk yang dipasarkan.

b. Untuk memantau realisasi biaya produksi.

c. Menghitung laba rugi bruto pada periode tertentu.

d. Menentukan harga pokok produk dalam proses dan produk selesai yang disajikan dalam neraca.

Menurut Mulyadi (2007:10) harga pokok produksi atau disebut harga pokok adalah pengorbanan sumber ekonomi yang diukur dalam satuan uang yang telah terjadi atau kemungkinan terjadi untuk memperoleh penghasilan. Mulyadi lebih lanjut menjelaskan bahwa, biaya produksi merupakan biayabiaya yang terjadi dalam hubunganya dengan pengolahan bahan baku menjadi barang jadi.

Harga pokok produksi atau product cost merupakan elemen penting untuk menilai keberhasilan (performance) dari perusahaan dagang maupun manufaktur. Harga pokok produksi mempunyai kaitan erat dengan indikator-indikator tentang sukses perusahaan, seperti laba kotor penjualan, laba bersih. Tergantung pada rasio antara harga jual dan harga pokok produknya, perubahan pada harga pokok produk yang relatif kecil bisa jadi berdampak signifikan pada indikator keberhasilanya. Harga pokok produksi pada dasarnya menunjukan harga pokok produk (barang dan jasa) yang diproduksikan dalam suatu periode akuntansi tertentu. Hal ini berarti bahwa harga pokok produksi merupakan bagian dari harga pokok, yaitu harga pokok dari produk yang terjual dalam suatu periode akuntansi. Perhitungan harga pokok produksi sangat mempengaruhi penetapan harga jual suatu produk sekaligus penetapan laba yang diinginkan. Dengan demikian ketetapan dalam melakukan perhitungan harga pokok produksi benar-benar diperhatikan karena apabila terjadi kesalahan dalam perhitungan akan menyebabkan kerugian bagi perusahaan. 


\section{Metode Penentuan Harga Pokok Produksi}

Metode penetuan harga pokok produksi adalah cara untuk memperhitungkan unsur-unsur biaya ke dalam harga pokok produksi. Dalam memperhitungkan unsur-unsur biaya ke dalam harga pokok produksi terdapat dua metode yaitu, metode pendekatan full costing dan variable costing.

1. Full costing

Penentuan harga pokok produksi yang memperhitungkan semua unsur biaya produksi kedalam harga pokok produksi yang terdiri dari biaya bahan baku, tenaga kerja langsung dan biaya overhead pabrik baik yang bersifat tetap maupun variabel. (Mulyadi, 2007:18). Jadi harga pokok produk yang dihitung dengan pendekatan full costing adalah biaya produksi ( biaya bahan baku, biaya tenaga kerja langsung, dan biaya overhead pabrik tetap dan variabel ditambah biaya non produksi( biaya pemasaran, biaya administrasi dan umum).

Penentuan harga pokok produksi dengan pendekatan full costing:

Biaya bahan baku

Biaya tenaga kerja langsung

Biaya overhead pabrik variable

Biaya overhead pabrik tetap

Harga pokok produksi

Biaya administrasi dan umum

Biaya pemasaran

Biaya komersil

Total harga pokok produksi $\mathrm{xxx}$

$\mathrm{xxx}$

$\mathrm{xxx}$

$\mathrm{xxx}$

\begin{tabular}{cr} 
& + \\
\hline $\mathrm{xxx}$ & \\
$\mathrm{xxx}$ & \\
$\mathrm{xxx}$ & \\
& + \\
\hline $\mathrm{xxx}$ & \\
& +
\end{tabular}

\section{Variable costing}

Menurut Mulyadi (2010:18) menyatakan bahwa variable costing merupakan metode penentuan harga pokok produksi yang hanya memperhitungkan biaya produksi yang berperilaku kedalam harga pokok produksi yang terdiri dari biaya bahan baku, biaya tenaga kerja langsung dan biaya overhead pabrik variabel.

Penentuan harga pokok produksi dengan menggunakan metode variable costing :

Biaya bahan baku

Biaya tenaga kerja langsung

$\mathrm{xxX}$

Biaya overhead pabrik variabel

$\mathrm{xxx}$

Harga pokok produksi variabel

$\mathrm{XxX}$

Biaya pemasaran variable

$\mathrm{xxX}$

Biaya administrasi umum dan variabel

$\mathrm{XXX}$

Biaya komersil

$\mathrm{xxx}$

Total biaya variabel

Biaya overhead pabrik tetap

Biaya pemasaran tetap

Biaya administrasi dan umum

Total biaya tetap

$\mathrm{XXX}$

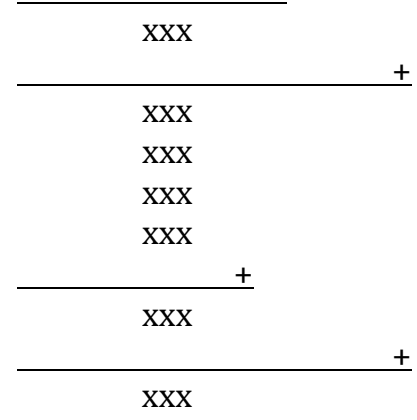

Total harga pokok produk

Beberapa hal yang perlu diperhatikan dari perbedaan laba rugi dalam metode full costing dan metode variable costing:

1. Dalam metode full costing terjadi penundaan sebagian biaya overhead pabrik tetap pada periode berjalan ke periode berikutnya bila tidak semua produk pada periode yang sama.

2. Dalam metode variable costing seluruh biaya tetap overhead pabrik telah diperlakukan sebagai beban pada periode berjalan, sehingga tidak terdapat bagian biaya overhead pada tahun berjalan yang dibebankan kepada tahun berikutnya. 
3. Jumlah persediaan akhir dalam metode variable costing lebih rendah dibandingkan metode full costing. Alasanya adalah dalam variable costing hanya biaya produksi variable yang dapat di perhitungkan sebagai biaya produksi.

4. Laporan laba rugi full costing tidak membedakan antara biaya tetap dan biaya variable, sehingga tidak cukup memadai untuk analisis hubungan biaya volume dan laba (CPV) dalam rangka perncanaan dan pengendalian.

Pada dasarnya tujuan penentuan harga pokok produksi adalah untuk menentukan secara tepat jumlah biaya perunit produk jadi, sehingga dapat diketahui laba atau rugi suatu perusahaan. Menurut Mulyadi (2007:41) manfaat dari penentuan harga pokok produksi secara garis besar adalah sebagai berikut:

a. Menentukan harga jual produk

Perusahaan yang berproduksi massa memproses produknya untuk memenuhi persediaan digudang dengan demikian biaya produksi dihitung untuk jangka waktu tertentu untuk menghasilkan informasi biaya peroduksi per satuan produk. Penentuan harga jual produk, biaya produksi per unit merupakan salah satu data yang dipertimbangkan disamping data biaya yang lain serta data non biaya.

b. Memantau realisasi biaya produksi

Manajemen memerlukan informasi biaya produksi yang sesungguhnya dikeluarkan dibandingkan dengan rencana produksi yang telah ditetapkan, oleh sebab itu akuntansi biaya digunakan dalam jangka waktu tertentu untuk memantau apakah produksi mengkonsumsi total biaya produksi sesuai dengan yang diperhitungkan sebelumnya.

c. Menghitung laba rugi periodik

Guna mengetahui apakah kegiatan produksi dan pemasaran perusahaan dalam periode tertentu mampu menghasilkan laba bruto. Manajemen memerlukan ketepatan penetapan laba periodik, sedangkan laba periodik yang tepat harus berdasarkan informasi biaya dan penentuan biaya yang tepat pula.

d. Menentukan harga pokok persediaan produk jadi dan produk dalam proses yang disajikan dalam neraca.

Saat manajemen dituntut untuk membuat pertanggung jawaban per periode, manajemen harus menyajikan laporan keuangan berupa neraca dan laporan laba rugi yang menyajikan harga pokok persediaan produk jadi dan harga pokok yang pada tanggal neraca masih dalam proses. Berdasarkan catatan biaya produksi yang masih melekat pada produk jadi yang belum dijual pada tanggal neraca serta dapat diketahui biaya produksinya. Biaya yang melekat pada produk jadi pada tanggal neraca disajikan dalam harga pokok persediaan produk jadi. Biaya yang masih melekat pada produk yang pada tanggal neraca masih dalam proses pengerjaan disajikan dalam neraca sebagai harga pokok persediaan produk dalam proses.

\section{Penetapan Harga Jual}

Keputusan penetapan harga jual sangat penting, karena selain mempengaruhi laba yang ingin dicapai perusahaan, juga mempengaruhi kelangsungan hidup perusahaan. Oleh karena itu dalam menentukan harga jual produk, tidak dapat dilakukan sekali saja tetapi harus selalu dievaluasi dan disesuaikan dengan kondisi yang sedang dihadapi perusahaan. Penentuan harga jual yang salah bisa berakibat fatal pada masalah keuangan perusahaan dan akan mempengaruhi kelangsungan usaha perusahaan tersebut seperti kerugian terus menerus. Penetapan harga tidak hanya sekedar perkiraan saja, tetapi harus dengan perhitungan yang cermat dan teliti yang harus diselesaikan dengan sasaran yang dituju oleh perusahaan. Harga merupakan nilai pengganti suatu barang untuk itu harga harus disesuaikan dengan kegunaan barang tersebut untuk konsumen.

Definisi harga menurut Basu Swastha (2005:241) adalah jumlah uang (ditambah beberapa produk kalau mungkin) yang akan dibutuhkan untuk mendapatkan sejumlah kombinasi dari produk dan pelayanan. Sedangkan menurut Philip Kotler dan Amstrong (2008:439), harga adalah sejumlah uang yang dibebankan atas suatu produk atau jasa, atau jumlah dari nilai yang ditukar konsumen atas manfaat-manfaat, karena memiliki atau menggunakan produk atau jasa tersebut.

Adapun dalam menetapkan harga jual, perusahaan harus jelas dalam menentukan tujuan yang hendak dicapai, karena tujuan tersebut dapat memberikan arah dan keselarahan pada kebijaksanaan yang diambil perusahaan. Menurut Philip Kotler (2008:638) adapun tujuan perusahaan dalam menetapkan harga yaitu :

1. Kelangsungan hidup

Perusahaan dapat mengejar kelangsungan hidup sebagai tujuan utamanya, jika mengalami kapasitas lebih, persaingan ketat, atau perubahan keinginan konsumen. Untuk menjaga agar pabrik tetap beroperasi dan persediaan dapat terus berputar, mereka sering melakukan penentuan harga. 
Laba kurang penting dibandingkan kelangsungan hidup. Selama harga dapat menutup biaya variabel dan sebagian biaya tetap, perusahaan dapat berjalan.

2. Laba sekarang maksimum

Banyak perusahaan yang menetapkan harga yang memaksimalkan labanya sekarang. Mereka memperkirakan bahwa permintaan dan biaya sehubungan sebagai alternatif harga dan akan memilih harga yang akan menghasilkan laba, arus kas, atau pengembalian investasi yang maksimum.

3. Pendapatan sekarang maksimum

Beberapa perusahaan menetapkan harga yang akan memaksimalkan pendapatan dari penjualan. Memaksimalkan pendapatan hanya membutuhkan perkiraan fungsi permintaan. Banyak manajer percaya bahwa memaksimalisasi pendapatan akan menghasilkan maksimalisasi laba jangka panjang dan pertumbuhan pasar.

Faktor biaya merupakan faktor penentu dari peusahaan, sehingga lebih mudah dalam menanganinya. Biaya juga menggambarkan batas minimum yang harus dipenuhi perusahaan untuk harga jual produknya. Menurut Basu Swastha (2005:154) metode penetapan harga jual yang berdasarkan biaya dalam bentuk yang paling sederhana, yaitu:

a. Cost plus pricing method

Penentuan harga jual cost pricing method, biaya yang digunakan sebagai dasar penentuan, dapat didefinisikan sesuai dengan metode penentuan harga pokok produk yang digunakan. Dalam metode ini, penjual atau produsen menetapkan harga untuk satu unit barang yang besarnya sama dengan jumlah biaya perunit, ditambah dengan suatu jumlah laba yang diinginkan. Dalam perhitungan cost plus pricing, digunakan rumus :

Harga Jual = Biaya Total + Margin

b. Mark up pricing method

Mark up pricing banyak digunakan oleh para pedagang. Para pedagang akan menentukan harga jualnya dengan cara menambahkan mark up yang diinginkan pada harga beli per satuan. Persentase yang ditetapkan berbeda untuk setiap jenis barang. Dalam menghitung harga jual, menggunakan rumus :

Harga Jual = Harga Beli + Mark up

c. Penentuan harga oleh produsen

Dalam metode ini, harga yang ditetapkan oleh perusahaan dari rangkaian harga yang ditetapkan oleh perusahaan-perusahaan lain dalam saluran distribusi. Karena itu penetapan harga oleh produsen memegang peranan penting dalam menentukan harga akhir barang. Dalam menetapkan harga jualnya, produsen dapat berorientasi pada biaya. Proses penetapan harga dimulai dengan menghitung biaya perunit barang yang dihasilkan, kemudian menambahkan sejumlah mark up tertentu. Produsen menggunakan rumus yang mereka anggap cocok bagi mereka. Tentunya berdasarkan pengamatan atas produk yang dihasilkanya.

\section{Kerangka Penelitian}

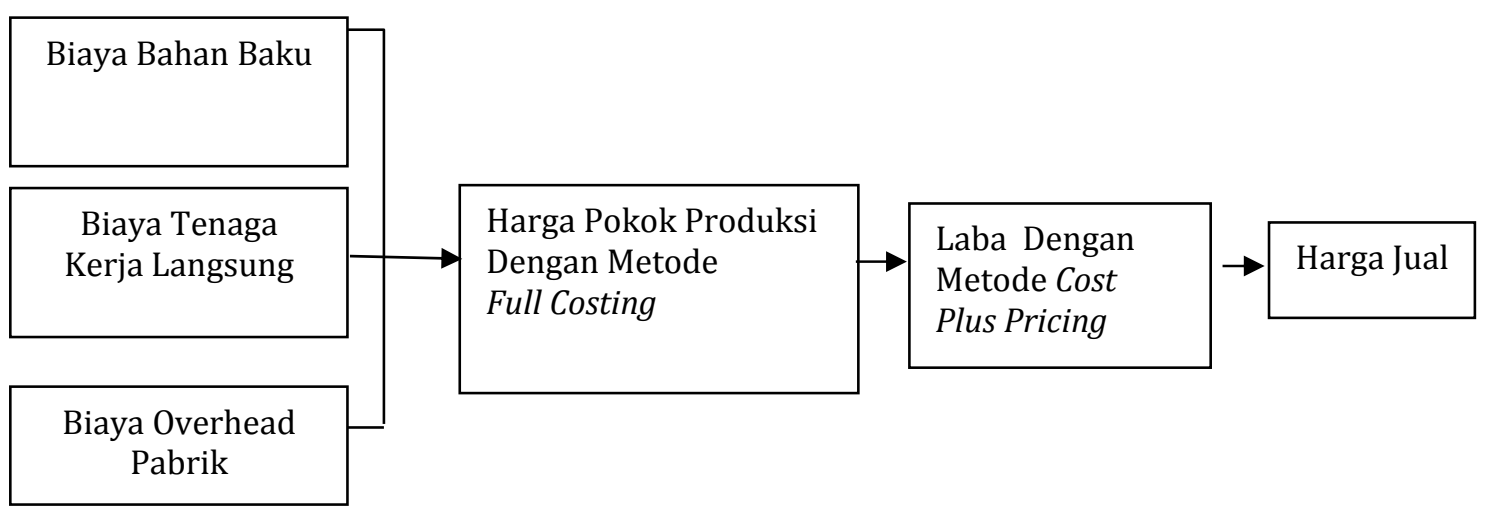

Gambar 1. Kerangka Penelitian

\section{METODE PENELITIAN \\ Jenis Penelitian}

Jenis penelitian yang digunakan adalah penelitian diskriptif yang mana suatu bentuk penelitian yang ditujukan untuk mendiskripsikan fenomena-fenomena yang ada, baik fenomena alamiah maupun 
fenomena buatan manusia. Fenomena ini biasanya berupa bentuk, aktivitas, karakteristik, perubahan, hubungan, kesamaan dan perbedaan antara fenomena yang satu dengan fenomena yang lainya (Sukmadinata, 2006:72).

\section{Metode Analisis}

a. Analisis kualitatif

Analisis ini digunakan untuk membahas dan menerangkan hasil penelitian dengan mempertimbangkan dan membandingkan antara biaya bahan baku dan biaya tenaga kerja langsung dalam penyusunan harga pokok produksi perusahaan dengan menggunakan keterangan-keterangan yang tidak berbentuk angka.

b. Analisis kuantitatif

1. Metode penetapan harga pokok produksi

Metode perhitungan harga pokok penuh ( full costing)

Menurut Mulyadi (2007:18), metode penentuan harga pokok produksi yang memperhitungkan semua unsur biaya produksi kedalam harga pokok produksi. Harga pokok produksi yang dihitung melalui pendekatan full costing terdiri dari unsur harga pokok produksi (biaya bahan baku, biaya tenaga kerja langsung, biaya overhead pabrik variabel dan tetap) ditambah dengan biaya non produksi ( biaya pemasaran, biaya administrasi dan umum ).

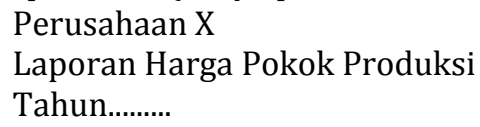

1. Biaya administrasi dan umum

2. Biaya pemasaran

Jumlah biaya komersil

Total biaya produksi

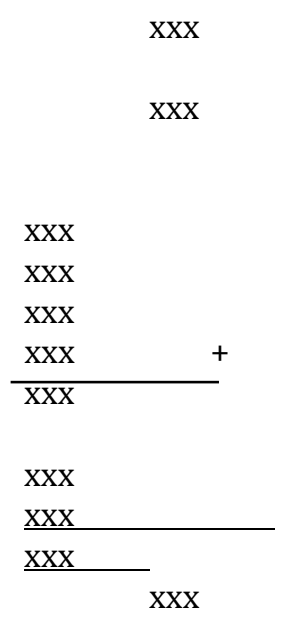

(Mulyadi, 2007:18)

2. Perencanaan laba

Didalam menentukan perencanaan laba menurut Hansen dan Mowen (2000:423) metode cost volume profit merupaka alat yang berguna untuk perencanaan dan pengambilan keputusan.

Perencanaan Laba $=$ Total Biaya $\mathrm{x}$ Laba

3. Metode penetapan harga jual

Dalam penetapan harga, menurut Basu Swastha (2005:154) metode yang digunakan adalah metode cost plus pricing, dimana perusahaan menentukan tingkat harga jual yaitu seluruh biaya total dijumlahkan dengan laba yang diharapkan oleh perusahaan sebesar $30 \%$.

Harga Jual $=$ Biaya Total + Margin

\section{HASIL PENELITIAN DAN PEMBAHASAN}

\section{Proses Produksi CV. Fortunna Advertising Kota Bengkulu}

CV. Fortunna Advertising Kota Bengkulu yang bergerak dibidang percetakan dan dimana produk yang dihasilkan berdasarkan pesanan dan sesuai dengan keinginan konsumen yaitu berdasarkan konsep yang mereka butuhkan dan tentunya hasil yang diharapkan dapat sesuai dengan pesanan. Secara umum 
bahan baku yang digunakan dalam pembuatan spanduk dan baliho adalah frontlite dan frontlie glossy dan tinta print mate. Peralatan yang digunakan dalam proses produksi yaitu beberapa unit komputer yang digunakan untuk mendesign spanduk dan baliho berdasarkan konsep dan pesanan konsumen. Dan satu unit mesin digital printing dengan Merek Gongzheng GZT 3204 AU 3,2 ML full colouruntuk mencetak hasil pesanan. Adapun proses produksinya yaitu konsumen harus memesan terlebih dahulu produk yang mereka butuhkan ke bagian administrasi seperti menentukan konsep, ukuran, dan jumlah yang mereka butuhkan, menentukan kapan waktu pesanan harus diselesaikan. Setelah pesanan diterima oleh bagian administrasi kemudian bagian administasi memberikan tanda terima pesanan kepada konsumen sesuai dengan kesepakatan bersama, lalu bagian administrasi menyerahkan konsep yang dipesan konsumen kepada kepala operator dan ditanda tangani. Kemudian kepala operator menyerahkan kebagian design dan bagian design membuat sesuai konsep yang diberikan. Setelah selesai di design, bagian design memberikan konsep kepada kepala operator karena kepala operator juga bertanggung jawab penuh atas kepuasan konsumen dan kepala operator mencocokan dengan konsep yang diterima setelah sesuai kemudian dicetak.

\section{Biaya Produksi Spanduk}

a. Biaya bahan baku

Dalam pembuatan spanduk pada CV. Fortunna Advertising Kota Bengkulu, bahan baku yang digunakan ialah frontlite. Dimana setiap bulannya perusahaan ini mampu menghabiskan bahan baku 7 sampai 12 roll, sedangkan 1 roll $=250$ meter. Berikut jumlah produksi CV. Fortunna Advertising Bengkulu tahun 2015, 2016, dan 2017.

Tabel 2. Jumlah Produksi Spanduk CV. Fortunna Advertising Kota Bengkulu Tahun 2015, 2016 dan 2017.

\begin{tabular}{|l|l|l|l|l|l|l|}
\hline \multirow{2}{*}{ Bulan } & \multicolumn{2}{l|}{ Tahun 2015 } & \multicolumn{2}{l|}{ Tahun 2016 } & \multicolumn{2}{l|}{ Tahun 2017 } \\
\cline { 2 - 7 } & Roll & Meter & Roll & Meter & Roll & Meter \\
\hline Januari & 3,5 & 875 & 4 & 1.000 & 5 & 1.250 \\
Februari & 6 & 1.500 & 5 & 1.250 & 7 & 1.750 \\
Maret & 5,5 & 1.375 & 6 & 1.500 & 4 & 1.000 \\
April & 5 & 1.250 & 5,5 & 1.375 & 4 & 1.000 \\
Mei & 4 & 1.000 & 4 & 1.000 & 3 & 750 \\
Juni & 7 & 1.750 & 5 & 1.250 & 4 & 1.000 \\
Juli & 6 & 1.500 & 6 & 1.500 & 5,5 & 1.375 \\
Agustus & 5,5 & 1.375 & 5 & 1.250 & 5,5 & 1.375 \\
September & 4 & 1.000 & 6 & 1.500 & 6 & 1.500 \\
Oktober & 6,5 & 1.625 & 5 & 1.250 & 3,5 & 875 \\
November & 8 & 2.000 & 8 & 2.000 & 6 & 1.500 \\
Desember & 7 & 1.750 & 7,5 & 1.875 & 7,5 & 1.875 \\
\hline Total & 68 & 17.000 & 67 & 16.750 & 61 & 15.250 \\
\hline
\end{tabular}

Sumber: Hasil Penelitian dan diolah, 2018

Berdasarkan tabel 2, dapat diketahui jumlah produksi yang dihasilkan pada setiap bulannya selalu berubah-ubah. Karena produk yang dihasilkan berdasarkan pesanan konsumen. Untuk pembuatan spanduk menggunakan bahan baku frontlitedan dimana bahan baku tersebut berisi 1 roll = 250 meter. Sehingga produksi pada setiap tahunnya dapat dikalkulasikan dengan cara sebagai berikut pada tahun 2015 menghabiskan bahan baku sebanyak 68 roll x 250 meter $=17.000$ meter. Dan untuk tahun 2016 menghabiskan 67 roll x 250 meter $=16.750$ meter. Sedangkan untuk tahun 2017 sebanyak 61 roll x 250 meter $=15.250$ meter.

Dengan mengetahui jumlah produksi kita dapat mengetahui biaya bahan baku yang dikeluarkan dalam pembuatan spanduk yang mana harga untuk bahan baku selalu mengalami kenaikan untuk setiap tahunnya sehingga dapat menyebabkan biaya bahan baku selalu mengalami perubahan setiap tahunnya. Untuk mengetahui biaya bahan baku yang dikeluarkan untuk setiap produk dapat mengkalkulasikan jumlah produksi yang dihasilkan setiap tahunnya. Berikut biaya bahan baku yang dikeluarkan untuk produksi spanduk pada CV. Fortunna Advertising Kota Bengkulu.

Tabel 3. Biaya Bahan Baku Spanduk pada Tahun 2015, 2016, 2017.

\begin{tabular}{|l|l|l|l|}
\hline \multirow{2}{*}{\multicolumn{1}{|c|}{ Keterangan }} & \multicolumn{3}{|c|}{ Tahun(Roll) } \\
\cline { 2 - 4 } & 2015 & 2016 & 2017 \\
\hline Harga bahan baku & Rp.1.785.000 & Rp.1.815.000 & Rp.1.850.000 \\
\hline Jumlah produksi & 68 & 67 & 61 \\
\hline Total BBB & Rp.121.380.000 & Rp.121.605.000 & Rp.112.850.000 \\
\hline
\end{tabular}

Sumber : Tabel 2 dan diolah, 2018 
Dari tabel 3 diatas, dapat diketahui harga untuk setiap bahan baku yang selalu mengalami kenaikan untuk setiap tahunnya sehingga dapat menyebabkan biaya bahan baku selalu mengalami perubahan setiap tahunnya. Untuk mengetahui biaya bahan baku yang dikeluarkan untuk setiap produk dapat mengkalkulasikan jumlah produk yang dihasilkan setiap tahunnya dikali dengan harga bahan baku setiap tahunnya.

b. Biaya Tenaga Kerja Langsung

Biaya tenaga kerja langsung merupakan upah yang diberikan kepada karyawan yang terlibat secara langsung dalam pembuatan spanduk pada CV. Fortunna Advertising jumlah karyawan sebanyak 4 orang dimana upah yang ditetapkan ialah Rp. 750 permeter. Maka biaya tenaga kerja dapat dihitung dengan cara mengalihkan upah permeter dikali dengan produksi yang dihasilkan dalam sebulan dikali dengan jumlah karyawan. Sehingga diketahui biaya tenaga kerja yang harus dikeluarkan pada CV. Fortunna Advertising setiap bulannya. Hasil perkalian dapat dilihat pada tabel dibawah ini.

Tabel 4. Biaya Tenaga Kerja Langsung Produksi Spanduk pada CV.Fortunna Advertising tahun 2015, 2016, dan 2017

\begin{tabular}{|l|l|l|l|}
\hline \multirow{2}{*}{ Bulan } & \multicolumn{3}{|c|}{ Tahun (Rp) } \\
\cline { 2 - 4 } & \multicolumn{1}{|c|}{2015} & \multicolumn{1}{c|}{2016} & 2017 \\
\hline Januari & 4.593 .750 & 5.250 .000 & 6.562 .500 \\
\hline Pebruari & 7.875 .000 & 6.562 .500 & 9.187 .500 \\
\hline Maret & 7.218 .750 & 7.875 .000 & 5.250 .000 \\
\hline April & 6.562 .500 & 7.218 .750 & 5.250 .000 \\
\hline Mei & 5.250 .000 & 5.250 .000 & 3.937 .500 \\
\hline Juni & 9.187 .500 & 6.562 .500 & 5.250 .000 \\
\hline Juli & 7.875 .000 & 7.875 .000 & 7.218 .750 \\
\hline Agustus & 7.218 .750 & 6.562 .500 & 7.218 .750 \\
\hline September & 5.250 .000 & 7.875 .000 & 7.875 .000 \\
\hline Oktober & 8.531 .250 & 6.562 .500 & 4.593 .750 \\
\hline November & 10.500 .000 & 10.500 .000 & 7.875 .000 \\
\hline Desember & 9.187 .500 & 9.843 .750 & 9.843 .750 \\
\hline Jumlah & 89.250 .000 & 87.937 .500 & 80.062 .500 \\
\hline
\end{tabular}

Sumber : Lampiran 1 dan diolah, 2018

Berdasarkan tabel 4 di atas, maka upah yang diberikan kepada karyawan CV. Fortunna Advertising Kota Bengkulu dengan cara mengkalkulasikan, sehingga total upah spanduk tahun 2015 yaitu 750 x 17.000 × 7 = Rp. 89.250 .000 untuk tahun 2016 yaitu 750 x 16.750 x 7 = Rp. 87.937 .500 dan untuk tahun 2017 yaitu $750 \times 12.250 \times 7=$ Rp.80.062.500

\section{c. Biaya Overhead Pabrik}

Biaya overhead pabrik merupakan seluruh biaya produksi kecuali biaya bahan baku dan biaya tenaga kerja langsung. Untuk pembebanan biaya overhead pabrik pada produk yaitu dengan membagi jumlah biaya overhead pabrik yang terjadi pada tahun 2015 sampai dengan 2017 terhadap seluruh jumlah produksi pada tahun yang bersangkutan. Adapun perhitungan secara rinci tentang biaya overhead pabrik pada CV. Fortunna Advertising Kota Bengkulu adalah sebagai berikut :

a. Biaya penolong (tinta)

Biaya penolong yang dimaksudkan disini ialah biaya tinta yang dikeluarkan dalam pembuatan spanduk atau bahan bantu yang digunakan untuk pembuatan spanduk dimana bahan penolong tersebut ialah tinja jenis print mateberikut rincian biaya yang dikeluarkan dan jumlah tinta yang habis digunakan selama tahun 2015, 2016, dan 2017

Tabel 5. Total Biaya Tinta Spanduk Tahun 2015, 2016, dan 2017

\begin{tabular}{|l|l|l|l|l|}
\hline \multirow{3}{*}{ Keterangan } & Tahun & \multirow{2}{*}{ Satuan } \\
\cline { 2 - 5 } & 2015 & 2016 & 2017 & Galon \\
\hline Jumlah tinta & 16 & 17 & 12 & Rupiah \\
\hline Harga tinta & 560.000 & 580.000 & 600.000 & Rupiah \\
\hline Total & 8.960 .000 & 8.700 .000 & 7.200 .000 & \\
\hline
\end{tabular}

Sumber : Hasil Penelitian dan diolah, 2018

Dari tabel 5 diatas, dapat diketahui bahwa jumlah tinta yang dikeluarkan untuk proses pembuatan spanduk berdasarkan kebutuhan yang diperlukan dalam pembuatan spanduk. Dimana harga tinta selalu berubah setiap tahunnya dan untuk mengetahui total biaya tinta dapat mengkalkulasikan jumlah tinta yang dikeluarkan setiap tahunnya dengan harga tinta setiap tahunnya. 
b. Biaya listrik

Biaya listrik yaitu biaya yang berhubungan dengan kegiatan produksi, dimana biaya tersebut digunakan untuk pengolahan bahan baku menjadi produk selesai. Adapun biaya listrik yang dikeluarkan untuk produksi spanduk selalu mengalami perubahan setiap tahunnya, untuk tahun 2015 sebesar Rp.15.470.000,- tahun 2016 sebesar Rp.15.192.250,- dan tahun 2017 Rp.13.298.000 biaya yang berubah-ubah setiap tahunnya berdasarkan jumlah produksi yang dihasilkan. Berikut rincian pembebanan setiap meter produk dengan cara membagi biaya listrik yang dikeluarkan dengan jumlah produksi yang dihasilkan.

Tahun 2015

Tahun 2016

Tahun 2017
Rp. 15.470.000,-

17.000 meter Rp. 15.192.250,-

16.750 meter

Rp. 13.298.000,-
$=$ Rp. $910,-/$ meter

$=$ Rp. 907,- $/$ meter

$=$ Rp. $872,-/$ meter

\subsection{0 meter}

c. Biaya telepon

Biaya telepon yaitu biaya penunjang dalam kegiatan produksi. Atau berkaitan dalam pembuatan spanduk. Adapun biaya yang dikeluarkan untuk produksi spanduk selalu berubah-ubah setiap tahun karena berdasarkan jumlah produksi pertahunnya. Pada tahun 2015 sebesar Rp.7.735.000,- tahun 2016 sebesar Rp.7.537.500,- sedangkan tahun 2017 Rp.6.786.250,- Berikut rincian pembebanan setiap meter produk dengan cari membagi biaya produksi yang dikeluarkan pertahun dengan jumlah produksi pertahun.

Rp.7.735.000,-

Tahun 2015

17.000 meter $=$ Rp. $455,-/$ meter

p. 7.537.500,-

Tahun 2016

$\frac{16.750 \text { meter }}{\text { Rp. } 6.786 .250,-}=$ Rp. $450,-/$ meter
15.250 meter

Tahun 2017

15.250 meter

d. Biaya penyusutan

Adapun penyusutan merupakan alokasi harga perolehan aktiva tetap menjadi beban karena terbatasnya manfaat yang dapat diperoleh darinya atau pengakuan adanya penurunan nilai aktiva tetap berwujud. Perhitungan penyusutan menggunakan metode garis lurus (stright line). Dalam metode ini beban penyusutan dialokasikan berdasarkan berlalunya waktu dalam jumlah yang sama, sepanjang masa manfaat aktiva tetap. Beban penyusutan tersebut dapat dihitung dengan rumus :

Tarif Penyusutan $=(\underline{\text { Harga Perolehan }- \text { Nilai Sisa })}$

Umur Ekonomis

Tabel 6. Rekapitulasi Pembebanan Biaya Overhead Pabrik untuk Produksi Spanduk pada CV. Fortunna Advertising Kota BengkuluTahun 2015, 2016, 2017.

\begin{tabular}{|c|c|c|c|}
\hline \multirow{2}{*}{ Jenis biaya } & \multicolumn{3}{|c|}{ Jumlah Biaya (Rp) } \\
\hline & 2015 & 2016 & 2017 \\
\hline a. Biaya tinta & 8.960 .000 & 8.700 .000 & 7.200 .000 \\
\hline b. Biaya listrik & 15.470 .000 & 15.192 .250 & 13.298 .000 \\
\hline c. Biaya telepon & 7.735 .000 & 7.537 .500 & 6.786 .250 \\
\hline d. Biaya penyusutan & & & \\
\hline - Penyusutan peralatan & 26.000 .000 & 26.000 .000 & 26.000 .000 \\
\hline - Penyusutan kendaraan & 5.000 .000 & 5.000 .000 & 5.000 .000 \\
\hline Total & 63.165 .000 & 62.429 .750 & 58.284 .250 \\
\hline
\end{tabular}

Sumber: Hasil Penelitan dan diolah, 2018 


\section{Analisis Harga Pokok Produksi Dengan Metode Full Costing, Perencanaan Laba dan Penetapan Harga Jual}

Berikut ini adalah perhitungan harga pokok produksi dengan metode full costing, perencanaan laba dan penetapan harga jual untuk spanduk pada tahun 2015, 2016, 2017.

a. Metode penetapan harga pokok produksi dengan menggunakan metode full costing.

CV. Fortunna Advertising Kota Bengkulu

Harga Pokok Produksi Spanduk

Tahun 2015

1. Biaya bahan baku

Rp.121.380.000

2. Biaya tenaga kerja langsung

Rp. 89.250.000

3. Biaya Overhead Pabrik

4. Biaya pemasaran

Rp. 63.165 .000

5. Biaya administrasi dan umum

Rp. 14.654 .000

Rp. $10.540 .000+$

Rp.298.989.000

Harga pokok produksi per meter $=$

Rp.298.989.000,-

17.000

Dari perhitungan tersebut dapat diketahui perencanaan laba yang diharapkan untuk spanduk dengan metode cost volume profit yaitu biaya total dikalkulasikan tingkat laba yang diharapkan oleh CV. Fortunna Advertising. Tingkat laba yang diinginkan usaha CV. Fortunna Advertising Bengkulu adalah 30 $\%$.

$$
\begin{aligned}
& \begin{aligned}
\text { Perencanaan Laba } & =\text { Biaya Total } \times \text { Laba } \\
& =298.989 .000 \times 30 \% \\
& =89.696 .700
\end{aligned} \\
& \text { perencanaan laba permeter }=\frac{89.696 .700,-}{17.000}
\end{aligned}
$$

Dengan mengetahui perencanaan laba yang diharapkan pada tahun 2015 sebesar 5.276,- permeter dapat di tentukan harga jual permeter dengan menambahkan biaya total dan perencanaan laba permeter sebagai berikut :

$$
\begin{aligned}
\text { Harga Jual } & =\text { Biaya Total }+ \text { Margin } \\
& =\text { Rp.17.587 }+5.276 \\
& =\text { Rp. } 22.863,--.
\end{aligned}
$$

b. Metode penetapan harga pokok produksi dengan menggunakan metode full costing.

CV. Fortunna Advertising Kota Bengkulu

Harga Pokok Produksi Spanduk

Tahun 2016

1. Biaya bahan baku

Rp.121.605.000

2. Biaya tenaga kerja langsung

Rp. 87.937.500

3. Biaya Overhead Pabrik

Rp. 62.429 .750

4. Biaya pemasaran

Rp. 13.785 .250

5. Biaya administrasi dan umum

$\frac{\text { Rp. } 10.267 .750+}{\text { Rp.296.025.250 }}$

\section{Rp.296.025.250-}

$$
\text { Harga pokok produksi per meter }=
$$

16.750

Dari perhitungan tersebut dapat diketahui perencanaan laba yang diharapkan untuk spanduk dengan metode cost volume profit yaitu biaya total dikalkulasikan tingkat laba yang diharapkan oleh CV. Fortunna Advertising. Tingkat laba yang diinginkan usaha CV. Fortunna Advertising Bengkulu adalah 30 $\%$.

$$
\begin{aligned}
\text { Perencanaan Laba } & =\text { Biaya Total } \times \text { Laba } \\
& =296.025 .250 \times 30 \% \\
& =88.807 .575,-
\end{aligned}
$$


Dengan mengetahui perencanaan laba yang diharapkan pada tahun 2016 sebesar 5.301,- permeter dapat di tentukan harga jual permeter dengan menambahkan biaya total dan perencanaan laba permeter sebagai berikut :

$$
\begin{aligned}
\text { Harga Jual } & =\text { Biaya Total }+ \text { Margin } \\
& =\text { Rp.17.637 }+5.301 \\
& =\text { Rp. } 22.938,-
\end{aligned}
$$

Dari perhitungan diatas dapat diketahui bahwa penetapan harga jual untuk produksi spanduk tahun 2016 yaitu Rp.23.063,- permeter.

c. Metode penetapan harga pokok produksi dengan menggunakan metode full costing.

CV. Fortunna Advertising Kota Bengkulu

Harga Pokok Produksi Spanduk

Tahun 2017
1. Biaya bahan baku
2. Biaya tenaga kerja langsung
3. Biaya Overhead Pabrik
4. Biaya pemasaran
5. Biaya administrasi dan umum

Rp.112.850.000

Rp. 80.062 .500

Rp. 58.284 .250

Rp. 12.749 .000

Rp. 8.311 .250

Rp.272.257.000

$$
\text { Harga pokok produksi per meter }=\frac{15.250}{=\text { Rp.17.852 }}
$$

Dari perhitungan tersebut dapat diketahui perencanaan laba yang diharapkan untuk spanduk dengan metode cost volume profit yaitu biaya total dikalkulasikan tingkat laba yang diharapkan oleh CV. Fortunna Advertising. Tingkat laba yang diinginkan usaha CV. Fortunna Advertising Bengkulu adalah 30 $\%$.

$$
\begin{aligned}
& \begin{aligned}
\text { Perencanaan Laba } & =\text { Biaya Total } \times \text { Laba } \\
& =272.257 .000 \times 30 \% \\
& =81.677 .100,-
\end{aligned} \\
& \text { perencanaan laba permeter }=\frac{81.677 .100,-}{15.250}=5.355,-
\end{aligned}
$$

Dengan mengetahui perencanaan laba yang diharapkan pada tahun 2017 sebesar 5.355,- permeter dapat di tentukan harga jual permeter dengan menambahkan biaya total dan perencanaan laba permeter sebagai berikut :

$$
\begin{aligned}
\text { Harga Jual } & =\text { Biaya Total }+ \text { Margin } \\
& =\text { Rp.17.852 }+5.355 \\
& =\text { Rp. } 23.207,-
\end{aligned}
$$

Dari perhitungan diatas dapat diketahui bahwa penetapan harga jual untuk produksi spanduk tahun 2017 yaitu Rp.23.207,- permeter.

\section{Pembahasan}

Tabel 7. Rekapitulasi Harga Pokok Produksi, Perencanaan Laba dan Penetapan Harga Jual Produksi Spnduk Pada CV.Fortunna Advertising Kota Bengkulu Tahun 2015, 2016, 2017.

\begin{tabular}{|l|c|c|c|}
\hline \multicolumn{2}{|c|}{ Keterangan } & \multicolumn{3}{c|}{ Spanduk (Rp) } \\
\cline { 2 - 4 } & 2015 & 2016 & 2017 \\
\hline Harga Pokok Produksi & 17.587 & 17.637 & 17.852 \\
\hline Perencanaan Laba & 5.276 & 5.301 & 5.355 \\
\hline Harga Jual & 22.863 & 22.938 & 23.207 \\
\hline
\end{tabular}

Sumber : Hasil Penelitian dan diolah, 2018

Dari hasil perhitungan untuk penentuan harga pokok produksi dengan metode full costing dan penetapan harga jual pada CV. Fortunna Advertising Kota Bengkulu telah dilakukan dengan baik, karena selama ini CV. Fortunna Advertising Kota Bengkulu telah memperhitungkan semua unsur produksi (biaya bahan baku, biaya tenaga kerja langsung dan biaya overhead pabrik) dan ditambah dengan biaya 
non produksi ( biaya pemasaran dan biaya administarsi dan umum). Hal ini menunjukkan bahwa perusahaan tersebut telah menerapkan perhitungan harga pokok produksi dengan metode full costing dalam memproduksi barang.

Dengan memakai metode full costingdan penentuan biaya berdasarkan pesanan maka CV. Fortunna Advertising Kota Bengkulu bisa mengetahui harga pokok dari produksi untuk menetapkan harga jual dengan tujuan mendapatkan laba yang sebesar mungkin, dan biaya yang dikeluar untuk produksi dapat dilaksanakan dengan efektip dan efisien. Perhitungan harga pokok produksi dengan metode full costing yang dilakukan oleh CV. Fortunna Advertising Kota Bengkulu sudah sesuai dengan pendapat Mulyadi (2007:18) yang menyatakan penentuan harga pokok yang memperhitungkan semua unsur biaya produksi kedalam harga pokok produksi yang terdiri dari biaya bahan baku, biaya tenaga kerja langsung dan biaya overhead pabrik yang bersifat variabel maupun tetap. Ditambah biaya non produksi yaitu biaya pemasaran, biaya administrasi dan umum.

Dari perhitungan yang dilakukan peneliti dengan menggunakan metode full costing dan dalam penetapan harga jual menggunakan metode cost plus pricingdengan tingkat laba sebesar $30 \%$. CV. Fortunna Advertising Kota Bengkulu dapat menekan biaya produksi agar lebih efektip dan dapat memperkecil perencanaan laba, dikarenakan banyaknya persaingan dalam usaha sejenis yang dapat menyebabkan daya jual yang menurun. Dengan menggunakan metode full costing dalam penentuan harga pokok produksi perusahaan dapat menentukan harga jual yang tepat dan dapat mengklasifikasikan setiap biaya yang ada dan dapat merencanakan keuangan perusahaan dengan baik . dengan metode full costing perusahaan dapat membuat laporan keuangan dengan tepat, dapat membuat keputusan yang tepat untuk kelangsungan tumbuh kembangnya perusahaan dimasa yang akan datang.

\section{Kesimpulan}

Dari hasil penelitian dan perhitungan harga pokok produksi pada CV. Fortunna Advertising Kota Bengkulu, dengan menggunakan metode full costing maka dapat ditarik suatu kesimpulan sebagai berikut :

a. Bahan baku yang digunakan CV. Fortunna Advertising Kota Bengkulu dalam pembuatan spanduk yaitu frontlite. Dan dimana 1 roll frontlite $=250$ meter, dan tinta yang digunakan yaitu print mate.

b. Harga pokok produksi yang dikeluarkan CV. Fortunna Advertising Kota Bengkulu dari masing-masing tahun selalu berubah karena harga bahan baku dan jumlah produksi yang dihasilkan selalu berubah.

c. Dalam penetapan harga jual pada CV. Fortunna Advertising Kota Bengkulu selalu berubah - ubah setiap tahunnya, dimana harga jual spanduk tahun 2015 Rp.22.863,- pada tahun 2016 harga jual spanduk Rp.22.938,- dan tahun 2017 harga jual Rp.23.207,-- sedangkan untuk baliho pada tahun 2015 sebesar Rp.26.052 untuk tahun 2016 Rp.26.010,- dan harga jual untuk tahun 2017 Rp.26.218,-

d. Dengan menggunakan metode full costing, perusahaan dapat mengkalsifikasikan setiap biaya yang dikeluarkan dan dapat membuat perencanaan keuangan perusahaan dengan tepat.

Saran

a. Sebaiknya CV. Fortunna Advertising Kota Bengkulu tetap melakukan analisa biaya produksi untuk produk yang dihasilkan, dengan pendekatan full costing, karena semua unsur biaya baik yang berprilaku tetap maupun variabel dimasukan dalam perhitungan.

b. Dalam penetapan tingkat laba CV. Fortunna Advertising harus tetap ber pepedoman pada hasil perhitungan harga pokok produksi yang sudah ditetapkan. Karena apabila terjadi kesalahan terhadap penetapan tingkat laba, maka akan mempengaruhi harga jual yang pada akhirnya akan berpengaruh terhadap kemampuan perusahaan dalam bersaing.

\section{DAFTAR PUSTAKA}

Ahmad, Firdaus dan Wasilah Abdullah. (2009). Akuntansi Biaya. Edisi 2. Jakarta: Salemba Empat.

Hall, James. A (Dewi Fitriasari dan Deny Arnos Kwary, Penerjemah). 2009. Sistem Informasi Akuntansi. Edisi 4. Jakarta: Salemba Empat.

Hansen \& Mowen. 2004. Manajemen Biaya, Edisi Bahasa Indonesia. Buku Kedua. Jakarta: Salemba Empat. Ikatan Akuntan Indonesia. 2007. "Standar Akuntansi Keuangan”. Jakarta: Salemba Empat.

Mulyadi, 2005. Akuntansi Biaya. Edisi Kelima. Yogyakarta ; UPPAMP YKPN

Muqodim, 2005. Teori Akuntansi, Edisi ke-1, Ekonisia, Yogyakarta.

rmanto, Witjaksono. 2006. Akuntansi Biaya. Edisi pertama. Yogyakarta. Penerbit: Graha Ilmu. Bastian sukirno, Sadono.2003. Pengantar Teori Mikro Ekonomi. Penerbit PT. Salemba,.

Sukmadinata, 2006. Metode Penelitian Kualitatif. Bandung : Graha Aksara 